\title{
A life exposed (and better for it)
}

\author{
Kjersti Aagaard is a practicing maternal-fetal medicine obstetrician at Texas Children's and Ben Taub Hospitals and \\ a reproductive biologist at Baylor College of Medicine. She studies a myriad of aspects of the microbiome, including \\ how it can influence pregnancy and the developing infant.
}

\section{Kjersti Aagaard}

am the middle child of two scientists
who fell in love in the late 1950s. My
Norwegian father was a renowned Arctic oceanographer, whose scientific observations on changing deep-ocean circulation patterns in the Bering Strait and across the North Pole were crucial to demonstrating recent trajectories of climate change. My American mother was a high school biology teacher who taught none other than Nobel Prize-winning biologist Linda Buck and later moved on to become a grassroots expert in land-use policy and environmental conservation. My parents modeled how to integrate scientific discovery with public advocacy, something that I would come to appreciate and use in my own work.

I was intent on pursuing a $\mathrm{PhD}$ and somewhat undecided on an MD, so I initiated graduate studies in Immunology at Mayo. Then, my somewhat charmed life hit a rather humbling speed bump. Following a series of events around my daughter's birth, I recognized that I was not in a healthy marriage. I began to see medical school as not just a means of becoming a physician scientist, but also a promise of financial independence. I completed my $\mathrm{PhD}$ and enrolled in medical school.

The next four years comprised the highest highs and lowest lows of my adult life. The mountain-top highs came from precious moments with my children, while the lows stemmed from my then-husband's struggles with alcoholism and addiction. During this tumultuous time, I took solace in the relatively orderly world of science and medicine. I would often seek out the preeminent geneticist Dr. Robert Gorlin, and we would debate the role of genes versus the environment in determining heredity and congenital disease. I became particularly interested in what mechanisms might render some pregnant women and their fetuses susceptible to not only teratogens, but also common environmental chemicals and exposures such as alcohol, cigarette smoke and air pollutants.

I had just given birth to our third child and was early in my residency when my

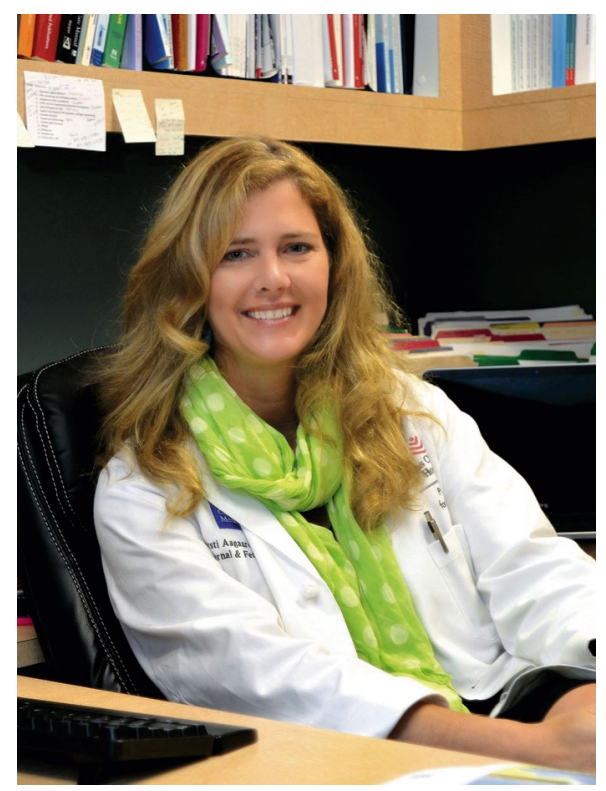

Credit: Kjersti Aagaard

marriage dissolved. I worried that others would assume that I, as a single mother, could not balance the heavy demands of academic obstetrics and family life. So I kept my single-mom status secret from most everyone. It wasn't until I was at the University of Utah that my mentors there provided an open forum to not only discuss top-notch science, but also helped me address my sense of vulnerability. Over time, their communicated respect for me as a dedicated mother and promising physician scientist rebuilt my sense of self. I was able to trust my abilities and intuition again, and I regained the courage to broaden my research to larger-scale genomic and epigenomic interrogations and clinical implementation studies. It was at this time that I began what would become over a decade of ongoing collaborations with colleagues at the Oregon National Primate Center, generating primate models for exploration of the impacts that maternal exposures have on a developing fetus.
When I arrived on the doorstep of Baylor College of Medicine and Texas Children's in 2007, I was eager to take on other unchartered scientific frontiers. This came to include my role in large-scale projects such as the Human Microbiome Project (HMP) as well as impactful translational research on the mechanisms underlying fetal programming. In the time since, my team and I have continued to work on questions surrounding how maternal diet and other pregnancy exposures alter offspring metabolism via epigenomic and metagenomic mechanisms. Similarly, our work on the placental, pregnancy and newborn microbiomes has systematically challenged the notion that babies are born with sterile guts. This has spurred public health and professional consensus statements that put a hold on unproven practices such as 'bacterial baptisms,' in which newborns delivered by Cesarean are wiped with their mother's vaginal microbes.

I've traversed some hills and valleys on the road leading to the discovery of my life's work. I emerged from those dark years of a troubled marriage to have not only a successful career as a clinician scientist, but also a marriage with the love of my life, Dr. Jim Versalovic, whom I met during our work on the HMP. Today I am living an immensely fulfilled and happy life that I am personally and professionally proud of. As my research continues, I hope to learn more about how, when and why negative exposures during pregnancy can alter life, both of the mother and her child. Ultimately, I hope to make others' journeys a little less bumpy - and infinitely more forgivingthan mine.

\section{Kjersti Aagaard}

Department of Obstetrics \& Gynecology and Division of Maternal-Fetal Medicine, Baylor College of Medicine and Texas Children's Hospital, Houston, TX, USA.

e-mail:aagaardt@bcm.edu

Published online: 6 February 2019

https://doi.org/10.1038/s41591-019-0341-6 